\title{
Impact of Adiposity and Fat Distribution, Rather Than Obesity, on Antibodies as an Illustration of Weight-Loss-Independent Exercise Benefits
}

\author{
Abdelaziz Ghanemi ${ }^{1,2}\left(\mathbb{D}\right.$, Mayumi Yoshioka $^{1}(\mathbb{D})$ and Jonny St-Amand ${ }^{1,2, *(\mathbb{D})}$ \\ 1 Functional Genomics Laboratory, Endocrinology and Nephrology Axis, \\ CHU de Québec-Université Laval Research Center, Québec, QC G1V 4G2, Canada; \\ Abdelaziz.Ghanemi@crchudequebec.ulaval.ca (A.G.); mayumi.yoshioka@crchudequebec.ulaval.ca (M.Y.) \\ 2 Department of Molecular Medicine, Faculty of Medicine, Laval University, Quebec, QC G1V 0A6, Canada \\ * Correspondence: jonny.st-amand@crchudequebec.ulaval.ca
}

Citation: Ghanemi, A.; Yoshioka, M.; St-Amand, J. Impact of Adiposity and Fat Distribution, Rather Than Obesity, on Antibodies as an Illustration of Weight-Loss-Independent Exercise Benefits. Medicines 2021, 8, 57. https://doi.org/10.3390/ medicines 8100057

Academic Editor: Abhishek Singh

Received: 8 September 2021

Accepted: 2 October 2021

Published: 8 October 2021

Publisher's Note: MDPI stays neutral with regard to jurisdictional claims in published maps and institutional affiliations.

Copyright: (c) 2021 by the authors. Licensee MDPI, Basel, Switzerland. This article is an open access article distributed under the terms and conditions of the Creative Commons Attribution (CC BY) license (https:/ / creativecommons.org/licenses/by/ $4.0 /)$.

\begin{abstract}
Obesity represents a risk factor for a variety of diseases because of its inflammatory component, among other biological patterns. Recently, with the ongoing COVID-19 crisis, a special focus has been put on obesity as a status in which antibody production, among other immune functions, is impaired, which would impact both disease pathogenesis and vaccine efficacy. Within this piece of writing, we illustrate that such patterns would be due to the increased adiposity and fat distribution pattern rather than obesity (as defined by the body mass index) itself. Within this context, we also highlight the importance of the weight-loss-independent effects of exercise.
\end{abstract}

Keywords: obesity; adiposity; antibodies; immunity

Obesity is one of most challenging health problems for the modern medicine and therapeutic research [1,2]. The main pattern that makes obesity challenging is that, once established, it is hard to reverse, probably because the new "set up" of the biological reference of body weight and adiposity as neuroendocrine adaptation changes with a broken energy homeostasis [3,4]. The current ongoing coronavirus disease 2019 (COVID-19) pandemic could worsen the obesity pandemic, which would negatively impact the development of this COVID-19 crisis [5,6], especially with the impact that the measures imposed by governments might have on immunity [7]. Therefore, it is of high importance to understand how obesity and adiposity impact the immunity and more specifically antibodies production and function. This is because vaccine-induced antibodies represent the best shot we have to end this pandemic.

Antibodies represent an important mediator and factor of the immune system [8]. On the other hand, obesity represents a status in which different biological and homeostatic processes, such as regeneration [9], energy balance [4] and neuroendocrine factors [3], are impaired or impacted. Within this context, we would like to put a spotlight on selected consequences and impacts obesity and adiposity have on antibody patterns in order to explain some immunological specificities reported in obese patients. Obesity is defined by an abnormal fat accumulation usually as a result of an unhealthy lifestyle that increases the energy intake to more than the energy expenditure [1,4], leading to a variety of health consequences [10,11] with increased impacts [5].

Regarding obesity-related antibody patterns, numerous results reflect the impacts obesity has on antibody properties. For instance, adaptive immune response to influenza virus is impaired during obesity [12], innate and adaptive immune responses against influenza are delayed in obese patient [13] and obesity was suggested to decline influenza antibody titers following influenza vaccination [14] as well as reduce vaccine efficacy [15] with poor vaccine immunogenicity [16]. Similarly, lower COVID-19 mRNA vaccine-induced antibody titers have been associated with central obesity [17] and severe acute respiratory syndrome 
corona Virus-2 IgG antibodies negatively correlate with body mass index in COVID-19 patients. This is important in the current pandemic context with the vaccination efforts aiming to end this global health crisis. Furthermore, one key concept in obesity is that obesity is an "autoinflammatory" disease characterized by a chronic and low-grade inflammation $[18,19]$, with several immune alterations including altered cell-mediated immune responses and leucocyte counts [20], principally in adipose tissue [21], where we have a localized inflammation [22]. Mechanisms beyond this are based on the links between obesity and both adipose tissue remodeling [23] and regulatory T cells [24]. Macrophage polarization [25], among other obesity-induced changes to macrophages [26], specifically due to adipocyte-macrophage interaction [27], are also involved within the inflammatory component of obesity.

The impacts obesity has on regeneration [9] could also explain, in part, such reduced antibody production due to the impaired regeneration immunity cells could have. Such observations would explain the reduced efficacy of vaccination in obese patients [28] as illustrated by the impaired immune response to influenza vaccination in obese humans [14] which could lead to recommend additional immunological stimulation (vaccination) for obese patients.

Exercise (combined or not with diet and/or pharmacological therapies) is among the most widely accepted approaches to controlling body weight and managing obesity [29-31]. Exercise has known benefits and effects on the immunity system [32,33] including antibodies [34], B lymphocytes [35], cytokines such as Interleukin-6 [36], antioxidant effects [37], regeneration adjuvants [38-40], and improved immunosurveillance and immunocompetence with an anti-inflammatory effects [41] via macrophage infiltration suppression [42]. Importantly, as illustrated above, the antibody-related immunity decline with obesity would be associated with the adiposity and its distribution rather than body weight [17]. This suggests that the benefits of exercise on antibodies for obese patients can be achieved even without weight loss, as illustrated by the reduced hepatic and visceral lipids following exercise training without weight loss [43]. The adiposity and fat distribution correlations, rather than body weight, with antibodies and immunity-related functions have been shown in other contexts such as inflammatory profiles [44,45] and IgG N-glycosylation [46]. Furthermore, central adiposity has been highlighted in correlation with other diseases $[47,48]$ and health problems as well $[49,50]$. In addition, acute exercise (and therefore independent of weight lost) has a broad impact on immune functions, including granulocytosis, lymphocytosis (antibody-producing cells) and monocytosis [51], increased natural killer cells [52], which are very responsive to acute exercise [53], increased lymphokine-activated killer cells activity [54] and enhanced T cell activity [55]. Importantly, acute exercise might promote a redistribution in lymphocyte subsets [56] including B cells that produce the antibodies $[57,58]$ and which are affected by obesity $[59,60]$ via diverse pathways including leptin-induced reduction in B cells function [61] as well. These benefits reverse most of those induced by adiposity described earlier (Figure 1).

Such concepts indicate and support the importance of exercise even without weight loss so that an interrelation between exercise and immunity regulation has been described [62]. The absence of weight loss does not mean the absence of fat loss or fat redistribution. Indeed, with exercise, body composition can improve toward increased muscle development and/or a new fat distribution but without body weight loss. This pattern could explain the benefits of exercise that does not lead to weight loss, which is of a particular importance since among the anti-obesity therapies (diet, pharmacology, etc.), exercise represents the one with the ability to shift the body composition as well as fat distribution beyond weight loss [63,64]. Moreover, indirect weight-loss-independent benefits of exercise can improve immunity, for instance by reducing hypertension [65] that is associated with lower post COVID-19 vaccination antibodies titers [17]. 


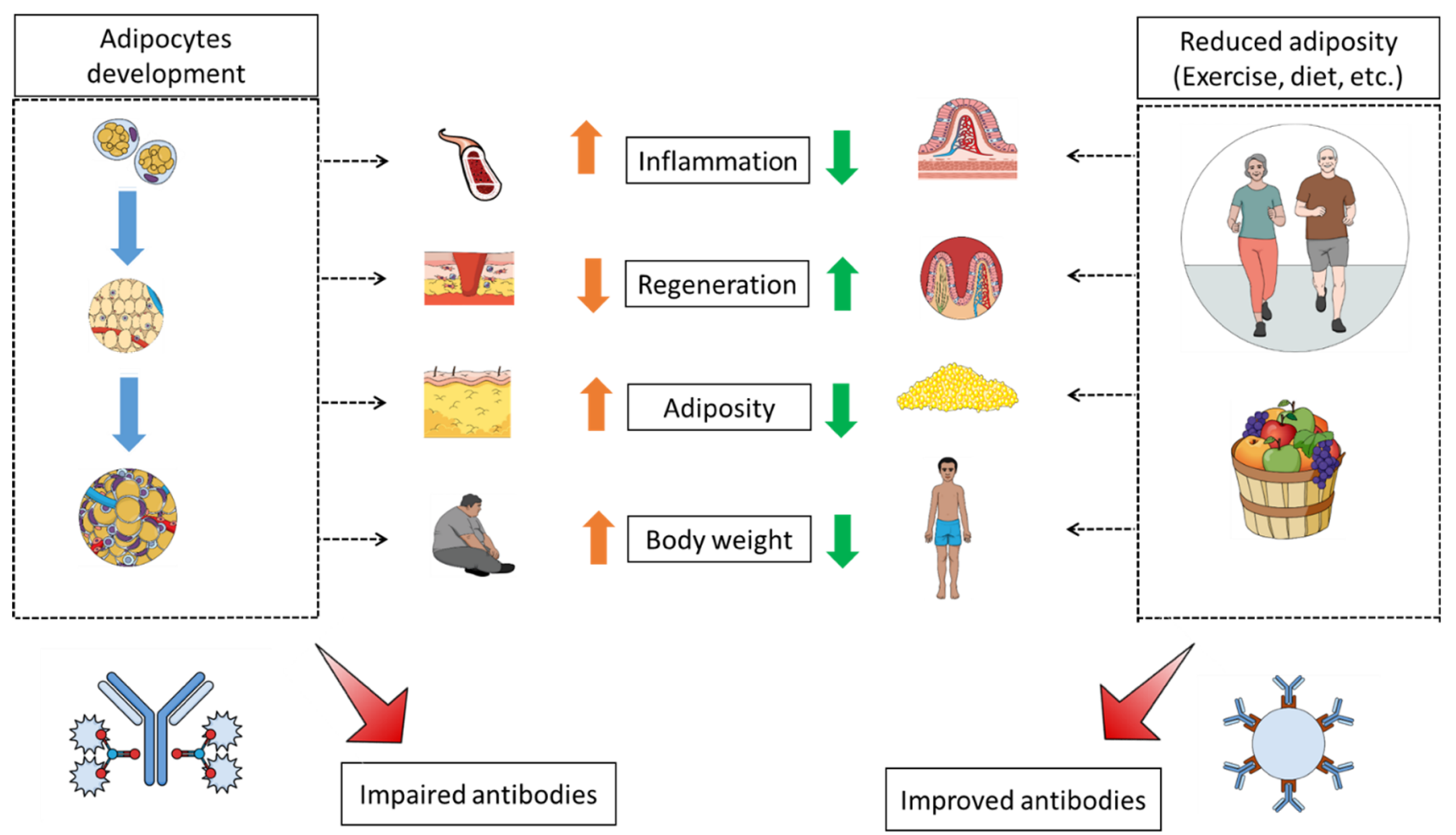

Figure 1. Antibody patterns and immunity performance between increased adiposity and exercise. Immunity functions and antibody-related patterns such as inflammation and regeneration are negatively impacted by adiposity development but corrected/improved by exercise and other adiposity-reducing approaches.

The benefits of exercise in the context of obesity are well documented in the context of energy balance, glucose metabolism, adiposity, muscles development, cardiorespiratory fitness and lipids profile [66-69]. However, within this piece of writing, we also illustrate the beneficial effects of exercise on obesity from an immunological perspective that focuses on antibodies. The interesting point is that the exercise effects are seen even with the absence of body weight loss. Therefore, this indicates that a focus on adiposity loss and fat distribution patterns [70] should replace the use of body weight as a medical parameter which correlates with the need to further focus, for instance, on waist circumference, which reflects to some extent visceral obesity, in clinical practice [71]. The concept of fat distribution and adiposity vs. overweight would also explain the concept "metabolically healthy obesity" [72,73], defined by body mass index that could lead to the concept of "immunologically healthy obesity".

We hope our work could represent an additional encouragement of physical activity and a healthy diet towards a better lifestyle for obese patients even if it does not necessarily lead to weight loss, especially that the benefits shown without weight loss are various and include decreased circulating interleukin-6 [74], reduced hepatic and visceral lipids [43], increased insulin sensitivity [75] and improved endothelium-dependent vasodilation [76]. The possible application of such concepts would be the prescription of exercise to improve the antibody properties of obese patients even if it does not lead to weight loss since, for the COVID-19 mRNA vaccine for instance, low antibody titers have been associated with a higher waist circumference rather than high body weights [17], suggesting, once more, that the impact would be due to the fat distribution (central vs. peripheral obesity) $[4,10]$ rather than increased body weight or even body fat percentage. Indeed, exercise can impact the body composition and fat distribution independently from body weight. This area of interaction between adiposity, fat distribution and immunology is worth further exploring in diverse contexts to develop new therapies, optimize the existing treatments and increase the awareness of how important weight-loss-independent effects of exercise are. 
Author Contributions: A.G. designed the manuscript structure and wrote it. A.G., M.Y. and J.S.-A. discussed the content and exchanged ideas and suggestions (concepts to add, references selection, etc.) throughout the writing process, edited and critically revised the paper. J.S.-A. gave the final approval for the version to be published. All authors have read and agreed to the published version of the manuscript.

Funding: This research received no external funding.

Institutional Review Board Statement: Not applicable.

Informed Consent Statement: Not applicable.

Data Availability Statement: Not applicable.

Acknowledgments: Abdelaziz Ghanemi received a Merit scholarship for foreign students from the Ministry of Education and Higher Education of Quebec, Canada, The Fonds de recherche du Québec-Nature et technologies (FRQNT) is responsible for managing the program (Bourses d'excellence pour étudiants étrangers du Ministère de l'Éducation et de l'Enseignement supérieur du Québec, Le Fonds de recherche du Québec-Nature et technologies (FRQNT) est responsable de la gestion du programme). Abdelaziz Ghanemi received the scholarship « Bourse Tremplin -Stage en milieu de pratique» (Internship scholarship) from the Fonds de recherche du Québec-Sante (FRQS), Quebec, Canada. Figure 1 was created using images from https://mindthegraph.com/ (accessed on 24 September 2021) and http:/ / smart.servier.com (accessed on 25 September 2021). Servier Medical Art by Servier is licensed under a Creative Commons Attribution 3.0 Unported License.

Conflicts of Interest: The authors declare no conflict of interest.

\section{References}

1. Ghanemi, A.; Melouane, A.; Yoshioka, M.; St-Amand, J. Exercise and High-Fat Diet in Obesity: Functional Genomics Perspectives of Two Energy Homeostasis Pillars. Genes 2020, 11, 875. [CrossRef]

2. Williams, E.P.; Mesidor, M.; Winters, K.; Dubbert, P.M.; Wyatt, S.B. Overweight and Obesity: Prevalence, Consequences, and Causes of a Growing Public Health Problem. Curr. Obes. Rep. 2015, 4, 363-370. [CrossRef] [PubMed]

3. Ghanemi, A.; Yoshioka, M.; St-Amand, J. Obesity as a Neuroendocrine Reprogramming. Medicina 2021, 57, 66. [CrossRef] [PubMed]

4. Ghanemi, A.; Yoshioka, M.; St-Amand, J. Broken Energy Homeostasis and Obesity Pathogenesis: The Surrounding Concepts. J. Clin. Med. 2018, 7, 453. [CrossRef]

5. Ghanemi, A.; Yoshioka, M.; St-Amand, J. Will an obesity pandemic replace the coronavirus disease-2019 (COVID-19) pandemic? Med. Hypotheses 2020, 144, 110042. [CrossRef] [PubMed]

6. Albashir, A.A.D. The potential impacts of obesity on COVID-19. Clin. Med. 2020, 20, e109-e113. [CrossRef] [PubMed]

7. Ghanemi, A.; Yoshioka, M.; St-Amand, J. Coronavirus Disease 2019 (COVID-19) Crisis: Losing Our Immunity When We Need It the Most. Biology 2021, 10, 545. [CrossRef]

8. Chaplin, D.D. Overview of the immune response. J. Allergy Clin. Immunol. 2010, 125, S3-S23. [CrossRef]

9. Ghanemi, A.; Yoshioka, M.; St-Amand, J. Regeneration during Obesity: An Impaired Homeostasis. Animals 2020, 10, 2344. [CrossRef] [PubMed]

10. Ghanemi, A.; St-Amand, J. Redefining obesity toward classifying as a disease. Eur. J. Intern. Med. 2018, 55, 20-22. [CrossRef]

11. Ghanemi, A.; Yoshioka, M.; St-Amand, J. Obese Animals as Models for Numerous Diseases: Advantages and Applications. Medicina 2021, 57, 399. [CrossRef]

12. Green, W.D.; Beck, M.A. Obesity Impairs the Adaptive Immune Response to Influenza Virus. Ann. Am. Thorac. Soc. 2017, 14, S406-S409. [CrossRef]

13. Honce, R.; Schultz-Cherry, S. Influenza in obese travellers: Increased risk and complications, decreased vaccine effectiveness. J. Travel Med. 2019, 26, taz020. [CrossRef] [PubMed]

14. Sheridan, P.A.; Paich, H.A.; Handy, J.; Karlsson, E.A.; Hudgens, M.G.; Sammon, A.B.; Holland, L.A.; Weir, S.; Noah, T.L.; Beck, M.A. Obesity is associated with impaired immune response to influenza vaccination in humans. Int. J. Obes. 2012, 36, 1072-1077. [CrossRef]

15. Honce, R.; Schultz-Cherry, S. Impact of Obesity on Influenza A Virus Pathogenesis, Immune Response, and Evolution. Front. Immunol. 2019, 10, 1071. [CrossRef]

16. Ovsyannikova, I.G.; White, S.J.; Larrabee, B.; Grill, D.E.; Jacobson, R.M.; Poland, G.A. Leptin and leptin-related gene polymorphisms, obesity, and influenza A/H1N1 vaccine-induced immune responses in older individuals. Vaccine 2013, 32, 881-887. [CrossRef] [PubMed]

17. Watanabe, M.; Balena, A.; Tuccinardi, D.; Tozzi, R.; Risi, R.; Masi, D.; Caputi, A.; Rossetti, R.; Spoltore, M.E.; Filippi, V.; et al. Central obesity, smoking habit, and hypertension are associated with lower antibody titres in response to COVID-19 mRNA vaccine. Diabetes Metab. Res. Rev. 2021, e3465. [CrossRef]

18. Esser, N.; Legrand-Poels, S.; Piette, J.; Scheen, A.J.; Paquot, N. Inflammation as a link between obesity, metabolic syndrome and type 2 diabetes. Diabetes Res. Clin. Pract. 2014, 105, 141-150. [CrossRef] 
19. Cox, A.J.; West, N.P.; Cripps, A.W. Obesity, inflammation, and the gut microbiota. Lancet Diabetes Endocrinol. 2015, 3, 207-215. [CrossRef]

20. de Heredia, F.P.; Gómez-Martínez, S.; Marcos, A. Obesity, inflammation and the immune system. Proc. Nutr. Soc. 2012, 71, 332-338. [CrossRef] [PubMed]

21. Lee, B.C.; Lee, J. Cellular and molecular players in adipose tissue inflammation in the development of obesity-induced insulin resistance. Biochim. Biophys. Acta 2014, 1842, 446-462. [CrossRef]

22. Karczewski, J.; Śledzińska, E.; Baturo, A.; Jończyk, I.; Maleszko, A.; Samborski, P.; Begier-Krasińska, B.; Dobrowolska, A. Obesity and inflammation. Eur. Cytokine. Netw. 2018, 29, 83-94. [CrossRef]

23. Sun, K.; Kusminski, C.M.; Scherer, P.E. Adipose tissue remodeling and obesity. J. Clin. Investig. 2011, 121, 2094-2101. [CrossRef]

24. Kucharska, A.M.; Pyrżak, B.; Demkow, U. Regulatory T Cells in Obesity. Adv. Exp. Med. Biol. 2015, 866, 35-40.

25. Li, C.; Xu, M.M.; Wang, K.; Adler, A.J.; Vella, A.T.; Zhou, B. Macrophage polarization and meta-inflammation. Transl. Res. 2018, 191, 29-44. [CrossRef] [PubMed]

26. Thomas, D.; Apovian, C. Macrophage functions in lean and obese adipose tissue. Metabolism 2017, 72, 120-143. [CrossRef]

27. Engin, A.B. Adipocyte-Macrophage Cross-Talk in Obesity. Adv. Exp. Med. Biol. 2017, 960, 327-343. [PubMed]

28. Beck, M.A. Influenza and obesity: Will vaccines and antivirals protect? J. Infect. Dis. 2012, 205, 172-173. [CrossRef]

29. Petridou, A.; Siopi, A.; Mougios, V. Exercise in the management of obesity. Metabolism 2019, 92, 163-169. [CrossRef] [PubMed]

30. Hsu, K.J.; Liao, C.D.; Tsai, M.W.; Chen, C.N. Effects of Exercise and Nutritional Intervention on Body Composition, Metabolic Health, and Physical Performance in Adults with Sarcopenic Obesity: A Meta-Analysis. Nutrients 2019, 11, 2163. [CrossRef] [PubMed]

31. Bray, G.A.; Frühbeck, G.; Ryan, D.H.; Wilding, J.P. Management of obesity. Lancet 2016, 387, 1947-1956. [CrossRef]

32. da Silveira, M.P.; da Silva Fagundes, K.K.; Bizuti, M.R.; Starck, É.; Rossi, R.C.; de Resende, E.S.D.T. Physical exercise as a tool to help the immune system against COVID-19: An integrative review of the current literature. Clin. Exp. Med. 2021, 21, 15-28. [CrossRef]

33. Alawna, M.; Amro, M.; Mohamed, A.A. Aerobic exercises recommendations and specifications for patients with COVID-19: A systematic review. Eur. Rev. Med. Pharmacol. Sci. 2020, 24, 13049-13055. [PubMed]

34. Suzuki, K.; Tagami, K. Voluntary wheel-running exercise enhances antigen-specific antibody-producing splenic B cell response and prolongs IgG half-life in the blood. Eur. J. Appl. Physiol. 2005, 94, 514-519. [CrossRef] [PubMed]

35. Fragala, M.S.; Kraemer, W.J.; Mastro, A.M.; Denegar, C.R.; Volek, J.S.; Kupchak, B.R.; Häkkinen, K.; Anderson, J.M.; Maresh, C.M. Glucocorticoid receptor expression on human B cells in response to acute heavy resistance exercise. Neuroimmunomodulation 2011, 18, 156-164. [CrossRef]

36. Ghanemi, A.; St-Amand, J. Interleukin-6 as a "metabolic hormone". Cytokine 2018, 112, 132-136. [CrossRef]

37. de Sousa, C.V.; Sales, M.M.; Rosa, T.S.; Lewis, J.E.; de Andrade, R.V.; Simões, H.G. The Antioxidant Effect of Exercise: A Systematic Review and Meta-Analysis. Sports Med. 2017, 47, 277-293. [CrossRef] [PubMed]

38. Smith, J.K. Exercise as an Adjuvant to Cartilage Regeneration Therapy. Int. J. Mol. Sci. 2020, 21, 9471. [CrossRef]

39. Schüttler, D.; Clauss, S.; Weckbach, L.T.; Brunner, S. Molecular Mechanisms of Cardiac Remodeling and Regeneration in Physical Exercise. Cells 2019, 8, 1128. [CrossRef]

40. Ghanemi, A.; Yoshioka, M.; St-Amand, J. Secreted Protein Acidic and Rich in Cysteine as A Regeneration Factor: Beyond the Tissue Repair. Life 2021, 11, 38. [CrossRef]

41. Scheffer, D.D.L.; Latini, A. Exercise-induced immune system response: Anti-inflammatory status on peripheral and central organs. Biochim. Biophys. Acta Mol. Basis Dis. 2020, 1866, 165823. [CrossRef] [PubMed]

42. Kawanishi, N.; Yano, H.; Yokogawa, Y.; Suzuki, K. Exercise training inhibits inflammation in adipose tissue via both suppression of macrophage infiltration and acceleration of phenotypic switching from M1 to M2 macrophages in high-fat-diet-induced obese mice. Exerc. Immunol. Rev. 2010, 16, 105-118. [PubMed]

43. Johnson, N.A.; Sachinwalla, T.; Walton, D.W.; Smith, K.; Armstrong, A.; Thompson, M.W.; George, J. Aerobic exercise training reduces hepatic and visceral lipids in obese individuals without weight loss. Hepatology 2009, 50, 1105-1112. [CrossRef] [PubMed]

44. Samouda, H.; de Beaufort, C.; Stranges, S.; Guinhouya, B.C.; Gilson, G.; Hirsch, M.; Jacobs, J.; Leite, S.; Vaillant, M.; Dadoun, F. Adding anthropometric measures of regional adiposity to BMI improves prediction of cardiometabolic, inflammatory and adipokines profiles in youths: A cross-sectional study. BMC Pediatr. 2015, 15, 168. [CrossRef]

45. Singh, S.; Sharma, A.N.; Murad, M.H.; Buttar, N.S.; El-Serag, H.B.; Katzka, D.A.; Iyer, P.G. Central adiposity is associated with increased risk of esophageal inflammation, metaplasia, and adenocarcinoma: A systematic review and meta-analysis. Clin. Gastroenterol. Hepatol. 2013, 11, 1399-1412. [CrossRef] [PubMed]

46. Liu, D.; Li, Q.; Dong, J.; Li, D.; Xu, X.; Xing, W.; Zhang, X.; Cao, W.; Hou, H.; Wang, H.; et al. The Association Between Normal BMI With Central Adiposity and Proinflammatory Potential Immunoglobulin G N-Glycosylation. Diabetes Metab. Syndr. Obesity Targets Ther. 2019, 12, 2373-2385. [CrossRef] [PubMed]

47. Ali, O.; Cerjak, D.; Kent, J.W.; James, R.; Blangero, J.; Zhang, Y. Obesity, central adiposity and cardiometabolic risk factors in children and adolescents: A family-based study. Pediatr. Obes. 2014, 9, e58-e62. [CrossRef] [PubMed]

48. Shang, X.; Scott, D.; Hodge, A.; Khan, B.; Khan, N.; English, D.R.; Giles, G.G.; Ebeling, P.R.; Sanders, K.M. Adiposity assessed by anthropometric measures has a similar or greater predictive ability than dual-energy X-ray absorptiometry measures for abdominal aortic calcification in community-dwelling older adults. Int. J. Cardiovasc. Imaging 2016, 32, 1451-1460. [CrossRef] [PubMed]

49. Zimta, A.A.; Tigu, A.B.; Muntean, M.; Cenariu, D.; Slaby, O.; Berindan-Neagoe, I. Molecular Links between Central Obesity and Breast Cancer. Int. J. Mol. Sci. 2019, 20, 5364. [CrossRef] 
50. Lin, T.Y.; Hung, S.C.; Lim, P.S. Central obesity and incident atherosclerotic cardiovascular disease events in hemodialysis patients. Nutr. Metab. Cardiovasc. Dis. 2020, 30, 500-507. [CrossRef] [PubMed]

51. Shinkai, S.; Shore, S.; Shek, P.N.; Shephard, R.J. Acute exercise and immune function. Relationship between lymphocyte activity and changes in subset counts. Int. J. Sports Med. 1992, 13, 452-461. [CrossRef] [PubMed]

52. Perna, F.M.; Schneiderman, N.; LaPerriere, A. Psychological stress, exercise and immunity. Int. J. Sports Med. 1997, 18, S78-S83 [CrossRef] [PubMed]

53. Timmons, B.W.; Cieslak, T. Human natural killer cell subsets and acute exercise: A brief review. Exerc. Immunol. Rev. 2008, $14,8-23$.

54. Horohov, D.W.; Dimock, A.; Guirnalda, P.; Folsom, R.W.; McKeever, K.H.; Malinowski, K. Effect of exercise on the immune response of young and old horses. Am. J. Vet. Res. 1999, 60, 643-647. [PubMed]

55. Lin, Y.S.; Jan, M.S.; Chen, H.I. The effect of chronic and acute exercise on immunity in rats. Int. J. Sports Med. 1993, 14, 86-92. [CrossRef]

56. Frisina, J.P.; Gaudieri, S.; Cable, T.; Keast, D.; Palmer, T.N. Effects of acute exercise on lymphocyte subsets and metabolic activity. Int. J. Sports Med. 1994, 15, 36-41. [CrossRef]

57. Tiller, T. Single B cell antibody technologies. N. Biotechnol. 2011, 28, 453-457. [CrossRef] [PubMed]

58. Rashidian, J.; Lloyd, J. Single B Cell Cloning and Production of Rabbit Monoclonal Antibodies. Methods Mol. Biol. 2020, $2070,423-441$.

59. Nicholas, D.A.; Nikolajczyk, B.S. B cells shed light on diminished vaccine responses in obesity. Obesity 2016, 24, 551. [CrossRef]

60. Shaikh, S.R.; Haas, K.M.; Beck, M.A.; Teague, H. The effects of diet-induced obesity on B cell function. Clin. Exp. Immunol. 2015, 179, 90-99. [CrossRef]

61. Frasca, D.; Ferracci, F.; Diaz, A.; Romero, M.; Lechner, S.; Blomberg, B.B. Obesity decreases B cell responses in young and elderly individuals. Obesity 2016, 24, 615-625. [CrossRef]

62. Wang, J.; Liu, S.; Li, G.; Xiao, J. Exercise Regulates the Immune System. Adv. Exp. Med. Biol. 2020, 1228, $395-408$.

63. Goedecke, J.H.; Micklesfield, L.K. The effect of exercise on obesity, body fat distribution and risk for type 2 diabetes. Med. Sport Sci. 2014, 60, 82-93. [PubMed]

64. Lee, S.; Kuk, J.L.; Davidson, L.E.; Hudson, R.; Kilpatrick, K.; Graham, T.E.; Ross, R. Exercise without weight loss is an effective strategy for obesity reduction in obese individuals with and without Type 2 diabetes. J. Appl. Physiol. 2005, 99, 1220-1225. [CrossRef]

65. Alpsoy, S. Exercise and Hypertension. Adv. Exp. Med. Biol. 2020, 1228, 153-167.

66. Ghanemi, A.; Melouane, A.; Yoshioka, M.; St-Amand, J. Exercise Training of Secreted Protein Acidic and Rich in Cysteine (Sparc) KO Mice Suggests That Exercise-Induced Muscle Phenotype Changes Are SPARC-Dependent. Appl. Sci. 2020, 10, 9108. [CrossRef]

67. Kirwan, J.P.; Sacks, J.; Nieuwoudt, S. The essential role of exercise in the management of type 2 diabetes. Cleve Clin. J. Med. 2017, 84, S15-S21. [CrossRef]

68. Keating, S.E.; Hackett, D.A.; Parker, H.M.; O'Connor, H.T.; Gerofi, J.A.; Sainsbury, A.; Baker, M.K.; Chuter, V.H.; Caterson, I.D.; George, J.; et al. Effect of aerobic exercise training dose on liver fat and visceral adiposity. J. Hepatol. 2015, 63, 174-182. [CrossRef] [PubMed]

69. Lemura, L.M.; Von Duvillard, S.P.; Andreacci, J.; Klebez, J.M.; Chelland, S.A.; Russo, J. Lipid and lipoprotein profiles, cardiovascular fitness, body composition, and diet during and after resistance, aerobic and combination training in young women. Graefe's Arch. Clin. Exp. Ophthalmol. 2000, 82, 451-458. [CrossRef] [PubMed]

70. Piché, M.E.; Tchernof, A.; Després, J.P. Obesity Phenotypes, Diabetes, and Cardiovascular Diseases. Circ. Res. 2020, 126, 1477-1500. [CrossRef] [PubMed]

71. Ross, R.; Neeland, I.J.; Yamashita, S.; Shai, I.; Seidell, J.; Magni, P.; Santos, R.D.; Arsenault, B.; Cuevas, A.; Hu, F.B.; et al. Waist circumference as a vital sign in clinical practice: A Consensus Statement from the IAS and ICCR Working Group on Visceral Obesity. Nat. Rev. Endocrinol. 2020, 16, 177-189. [CrossRef]

72. Blüher, M. Metabolically Healthy Obesity. Endocr. Rev. 2020, 41, 405-420. [CrossRef]

73. Iacobini, C.; Pugliese, G.; Blasetti Fantauzzi, C.; Federici, M.; Menini, S. Metabolically healthy versus metabolically unhealthy obesity. Metabolism 2019, 92, 51-60. [CrossRef] [PubMed]

74. Dekker, M.J.; Lee, S.; Hudson, R.; Kilpatrick, K.; Graham, T.E.; Ross, R.; Robinson, L.E. An exercise intervention without weight loss decreases circulating interleukin-6 in lean and obese men with and without type 2 diabetes mellitus. Metabolism 2007, 56, 332-338. [CrossRef] [PubMed]

75. Duncan, G.E.; Perri, M.G.; Theriaque, U.W.; Hutson, A.D.; Eckel, R.H.; Stacpoole, P.W. Exercise Training, Without Weight Loss, Increases Insulin Sensitivity and Postheparin Plasma Lipase Activity in Previously Sedentary Adults. Diabetes Care 2003, 26, 557-562. [CrossRef] [PubMed]

76. Mestek, M.L.; Westby, C.M.; Van Guilder, G.P.; Greiner, J.J.; Stauffer, B.; DeSouza, C.A. Regular Aerobic Exercise, Without Weight Loss, Improves Endothelium-dependent Vasodilation in Overweight and Obese Adults. Obesity 2010, 18, 1667-1669. [CrossRef] [PubMed] 